\title{
To Claim or Not to Claim? How Territorial Value Shapes Demands for Self-Determination
}

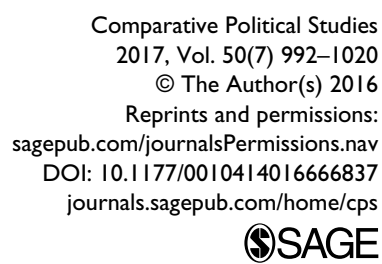

Comparative Political Studies (C) The Author(s) 2016

Reprints and permissions: gepub.com/journalsPermissions.nav OI: $10.1177 / 0010414016666837$ @SAGE

\section{Friederike Luise Kelle'}

\begin{abstract}
The literature on nationalism and civil war provides compelling evidence that territory is highly identity-relevant and strongly associated with conflict. However, it remains unclear which territorial characteristics determine this process, and how groups demanding self-determination differ from their counterparts not seeking greater rights. I argue that groups claim self-rule if they assign symbolic relevance to their land in contrast to material or strategic value, due to the positive effect of symbolic attachments on group cohesion. I present new data on the value of territory and self-determination demands, and propose a new and comprehensive measure of symbolic territory. The findings reveal that variation in symbolic value shows a considerably stronger association with self-determination demands than material and strategic territory. This highlights new research avenues investigating the role of territorial value in subnational conflicts, as well as the systematic differences in conflict behavior between groups demanding self-rule and non-disputants.
\end{abstract}

\section{Keywords}

conflict processes, subnational politics, civil war, self-determination, ethnicity, politics

\footnotetext{
'University of Konstanz, Germany
}

\section{Corresponding Author:}

Friederike Luise Kelle, Graduate School of Decision Sciences, University of Konstanz, Universitaetsstrasse 10, 78457 Konstanz, Germany.

Email: friederike.kelle@uni-konstanz.de 


\section{Introduction}

Loch Lomond, located northwest of Glasgow, is said to be the most beautiful lake of Scotland. It is not only a famous tourist destination but is also characterized by popular Scottish attachment, illustrated by the song "The bonnie banks of Loch Lomond." Allegedly going back to a letter of a Highlander rebel imprisoned after the Jacobite Uprising of 1745, the song was composed in the mid-19th century. The prisoner's longing for his home and lover is deeply connected to Loch Lomond: Only at the "bonnie banks of Loch Lomond" could the broken heart of the rebel, sentenced to death, be healed again. Today, there exist quite a number of contemporary and popular versions of the folk tune, which is sung on various occasion, at parties, and whenever Scotland plays sports (Purser, 1992).

Many communities worldwide cherish narratives similar to the tale of Loch Lomond. In tying together group identities, national narratives, and territory, the stories shape intra- and intergroup interactions and affect social identity. This article assesses the relevance of this territorial value in demands for selfdetermination (SD). I adopt the notion that group identity and territorial characteristics are not only closely interrelated, but that territorial value also provides strong incentives for territorially concentrated groups to seek selfgovernance. While the nationalism literature establishes the crucial character of territorial characteristics for collective identities in nationalist endeavors (Penrose, 2002; White, 2000), it is not clear why exactly territorially concentrated groups perceive their land as valuable and how this translates into claims for self-government. I suggest that this gap in knowledge results from theoretical analyses and measurement strategies, which do not allow for large-scale, comparative analyses across countries. The literature concerned with SD demands has developed a nuanced understanding of the relevance of individual aspects of symbolic territorial value in (violent) conflicts but does not provide a comprehensive assessment of different measures across cases. Comparative quantitative studies of conflict regard territory mostly as a relational feature or as a container for resources, while suggesting that conflicts and civil wars are potentially motivated or affected by diverse territorial features. Furthermore, most of the literature concerned with conflicts over self-governance focuses on civil war cases, mostly disregarding the establishment of a general mechanism accounting for the incidence of the demands in general. Given these shortcomings, I argue that a new theoretical approach is required that provides the conceptual basis for systematic comparison of claiming groups to non-contesters in order to identify the sources of SD demands.

Developing a new theory of territorial claim-making, this article seeks to address the question of how territorial value affects the incidence of subnational 
demands for SD. I argue that the presence of symbolically valuable territory is a much stronger and consistent predictor than material or strategic territory for explaining which groups demand self-rule, given its potential to increase the cohesion and thereby the mobilization capacity of the group. The article extends on existing work that either relies on incomplete proxies or excludes symbolic value from the analysis altogether. To assess the role of territory in SD struggles in general, I compare groups making demands for SD with nondisputing communities.

Based on the new collection of socially relevant groups in the "All Minorities at Risk" (AMAR) project (Birnir et al., 2014) and the list of SD groups in the Peace and Conflict Report 2005 (Marshall \& Gurr, 2005), I collect new data and supplement them with information on material and strategic characteristics of territory. In addition, I develop a new indicator of symbolic territorial value, which measures the extent to which a group values the land it inhabits based on its specific characteristics. Four broader patterns of symbolic value ascription emerge empirically. First, political features include the domination of historical kingdoms and lost autonomy, whereas, second, religious characteristics refer to, for instance, the presence of sacred sites. Third, cultural features affect value ascription when the land has particular relevance for the lifestyle and collective identity of the group. Finally, land rights issues, such as cases where groups were dispossessed or forcefully resettled, are relevant for symbolic territorial attachments.

A potential concern with this new indicator of symbolic value is the potential for endogeneity in the measurement. I use several strategies and tests to eliminate this issue at different stages of the project. First, I code any of the four patterns of symbolic value only if my sources suggest that the origin of symbolic value existed or occurred chronologically prior to the SD demand ${ }^{1}$ (online appendix). The source of symbolic value existed in almost all cases for a significant period before the start date of the demand, and in all cases prior to the onset of the claim. Second, the baseline specification of symbolic value, where at least two of the four dimensions of symbolic value are relevant to the group territory, increases the validity of the indicator even if there should be an unidentified bias in the value coding. Finally, I compare this original specification to a more liberal and a more conservative specification of the variable, which yields similar results.

The findings show that the probability that a group demands SD is high when the territory is symbolically valuable and the chances for SD claims increase when the territory is strategically relevant. However, the association between material value and SD incidence is not robust.

The article is organized to first introduce the theoretical assumptions and develop hypotheses on territorial value in SD conflicts, followed by a 
description of the data set and the data collection process, which also introduces the new measure of symbolic value. The subsequent sections present and evaluate the results, including alternative model specifications. The article closes with concluding remarks and issues for future research.

\section{Territory in Conflicts over Self-Determination}

\section{Lessons From the Literature}

The argument forwarded in this article adopts the notion that territory is critical for understanding the development and salience of group identities and nationalist sentiments. The nationalism literature has shown that groups seeking self-governance ${ }^{2}$ "derive their identities to a large degree from particular places and territories, and . . control of these is essential" (White, 2000, p. 10). Territory is central to nationalists, because the physical characteristics of the land are merged into the national identity, blending territory with identity features such as language or a shared history (Etherington, 2010). Individuals and groups have strong incentives to value the land they depend upon, and, if possible, to control it (Etherington, 2010, p. 4). By responding to "both the material requirements of life and the emotional requirements of belonging," territoriality as control over a geographical area constitutes a major source of power (Penrose, 2002). Providing the tangible and intangible sources of survival, guaranteed access to the land through territorial control ensures maximal security.

However, the "general acceptance of the significance of territory to nationalism has not been balanced by an understanding of just what it is that makes territory so significant to this ideology" (Penrose, 2002, pp. 277, accentuation original). Beyond the empirical finding and theoretical description of the phenomenon, the nationalism literature provides no generalizable answers to the question how and why nationalists relate to territory (Etherington, 2010, p. 337). This gap severely limits the understanding of the process through which territory gains salience for communities, because "to become national, shared memories must attach themselves to specific places and definite territories" (Smith, 1996, p. 453). Within the context of a homeland, "monasteries, fields and even trees become sites of national importance; where battles took place, ancient monarchs were crowned, or even where God revealed himself to a chosen people" (Etherington, 2010, p. 327). However, "the subjective components of national identity frequently are not addressed because they are difficult to measure" (White, 2000, p. 6). What is therefore needed is a coherent theoretical argument accounting for the relevance of territory for nationalists, which allows for large-scale, comparative analysis across countries. 
While the nationalism literature sets the stage for the development of an analytical and empirical framework of analysis of territorial value in SD demands, it provides limited guidance for approaching this challenge. I therefore tie in with the literature on civil war and subnational conflicts, which provides compelling theoretical arguments and empirical findings accounting for the origins of SD struggles. Groups are found to be most likely to engage in struggles for self-governance if they are politically excluded and discriminated against, receive external support, enjoyed autonomy in the past, if they are strategically strong vis-à-vis the state, and if the state made prior concessions toward other claimants. Furthermore, instability of the state, ethnic fears, and rent-seeking elites can trigger SD demands. Larger groups that are territorially concentrated, inhabit resource-rich regions, or experience a different level of economic development compared with the state have higher chances to claim greater rights (Jenne, Saideman, \& Lowe, 2007; Toft, 2012).

However, two concerns arise from these approaches. The first is that the majority of the arguments account solely for the development of violent demands. A large share of the analyses compares civil war cases to a heterogeneous baseline category, which combines non-events, where no conflict developed, and conflict events, that either did not escalate or involved only a limited degree of violence into one category. As a result, variation across types of events requires increased attention. ${ }^{3}$ Recent work focuses more explicitly on the specific character of nonviolent conflicts and the diffusion potential of nonviolent campaigns (Chenoweth \& Lewis, 2013; Gleditsch \& Rivera, 2015), and Cunningham (2013b) takes the study of nonviolent conflict events into the realm of SD struggles. While these studies shed light on the varying sources of strategies, they are not designed to contribute to a more systematic understanding of the differences between groups demanding SD and groups not disputing their status. I argue that an improved understanding of the systematic differences between these group types is equally important, as well as analytically prior, in improving our knowledge about the sources of SD strategies.

The second concern with existing explanations for SD conflicts is that the complex role of territory in group struggles for self-governance remains largely understudied. While individual territorial features, including geographic location of groups (Buhaug, 2006), or the loss of autonomy (Siroky $\&$ Cuffe, 2015) are studied separately, comprehensive comparative analysis of the territorial sources of SD demands is nearly absent. ${ }^{4}$ Furthermore, existing measures of symbolic value are incomplete. Approaches either theorize indirect links between territory and its salience using empirical proxies, such as the length of residence in an area and loss of autonomy, or investigate individual aspects of symbolic value such as sacred spaces or homeland 
territory. These measures cannot fully capture the relevance of territory in SD disputes. They imply that groups value their land only if it holds sacred sites or qualifies as their homeland, and exclude those cases where groups experience symbolic attachments for other reasons, such as dispossession from their lands. To develop an empirical basis for the required new theory of claim-making, I therefore seek to conduct a comprehensive comparative analysis of different elements defining territorial value and compose an integrated measure of symbolic territorial value, which does justice to the richness of prior work.

\section{How Territory Matters}

Territory and Self-Determination. My theory of SD claim-making proposes that the saliency of territorial value in SD demands stems from two sources. First, from a conceptual point of view, territory is critical for SD conflicts given the strong territorial component of both the demands for, and the practical execution of, all types of autonomy, separatism, and self-governance. Because sovereignty and political power are exercised over a defined area of territory and its inhabitants (Herb, 1999, p. 10), SD inherently involves the control of a distinct space and a clearly defined populace. Both scope-related demands, such as the call for greater language rights, as well as structural claims concerned with the organization of the state, including the formation of a regional parliament (Cunningham, 2013a, p. 1), relate to territorial control. The effort to promote the interests of a group, whether concerning language rights or outright secession, is therefore territorial.

Second, and empirically more tangible, is the practical aspect of territorial value in SD conflicts. My theory of claim-making proposes that territorial value contributes to the development of strong and cohesive group identities, which benefit the mobilization of collective group actors. The spatial distribution of the group members affects how easily communities are able to mobilize for SD as a function of the potential for overcoming the free rider problem. Toft (2003) shows that territorial concentration is associated with greater capability of the groups, as well as increased legitimacy of their claims. While urban groups tend to have little psychological connection to the territory, the ability of dispersed groups to put a demand into practice is limited. With a clearly defined territory, groups are more likely to develop a perception of belonging and entitlement to the land. Once the demand for territorial control is made, violent conflict ensues, if the host state, afraid to set precedent for other potential claimants, conceives of the land as indivisible and refuses to grant rights to self-rule (Toft, 2003). Weidmann (2009) terms this the motivational quality of the land. Territory can also provide an opportunity, as the 
relatively intensive interactions of members of regionally based communities promote shared identities and perceptions of spatial and social belonging as well as of potential threats. Spatially proximate group members enjoy stronger intragroup networks that are beneficial in the mobilization of supporters or resources, adding more leverage to a demand (Toft, 2003). I argue that the comparative ease of resource mobilization for conflict benefits all politically active groups independent of the strategy chosen.

While Toft's and Weidmann's argument is specific to violent actors, I argue that the increased mobilization potential of territorially concentrated groups benefits both nonviolent and violent conflict strategies, as strong networks and persistent interactions are critical for overcoming collective action problems. In fact, proximity and shared territory have been found to affect the capacity to overcome the problem of free riding (Hechter \& Okamoto, 2001). Conditional on the individual's degree of dependence on the group, the incentives for in-group cooperation can be significant. These include the collective capacity to monitor and socially sanction the defection of group members, as well as the character and extent of social rewards for cooperation. Enduring interactions increase the degree of norm internalization and therefore augment the chances that an individual will choose cooperation over free riding. In short, mutual dependence is the most reliable predictor of successful mobilization (Hechter \& Okamoto, 2001, p. 202 ff.).

In sum, spatially proximate group members have higher chances to develop shared identities, and face comparatively lower organization costs for the coordination of collective action (Weidmann, 2009). Empirically, territorially concentrated majorities have a higher probability of experiencing indivisible territorial conflicts, due to the increased perceived legitimacy and credibility of territorial claims and reduced mobilization costs (Toft, 2002). Siroky and Cuffe (2015) show that groups are more likely to secede if they benefit from increased mobilization capacity due to prior autonomous status, and if they suffer from grievances against the government, that can no longer credibly commit following the group's loss of self rule. In contrast to currently autonomous groups and those that never enjoyed the right to selfrule, formerly self-governed communities will thus be more successful in mobilizing for secession.

My theory therefore states that groups are more likely to demand SD if the territory they inhabit is symbolically valuable. Symbolic attachments facilitate the mobilization of group members by increasing group cohesion and providing a powerful focal point of identification, which allows for social and political control. The specification of the homeland is in fact not arbitrary but relies on territorial focal principles, such as natural frontiers (Goemans, 2006). Symbolic territory differs from materially or strategically valuable terrain in 
the effect on group identity and cohesion, and therefore on the conditions for the formation of SD demands. Unlike symbolically valuable terrain, the latter two do not directly affect the strength of intragroup identification. Instead, they either provide, for instance, sources of grievances from resource extraction affecting group cohesion in the context of material value, or, in the case of strategic terrain, strengthen conditions favorable for violent conflict. However, resentment might also result from events associated with symbolic attachments to the land. ${ }^{5}$ The loss of autonomy or the expulsion from the homeland is indicative of this process. Palestinian refugees, for instance, fled or were expelled from their homes during the wars of 1948 and 1967 between Israel and its Arab neighbors. Now living in the West Bank, Gaza, Jordan, Lebanon, and Syria, often still in refugee camps, the right to return is neglected to the refugees. Many kept the deeds and keys to the houses they left behind, which have either been occupied or demolished. Nonetheless, the wish to return is strong even in the descendants of the expelled, for many even nonnegotiable. The loss of the homeland therefore generated grievances for the Palestinian population, and the demand to return home dominates much of Palestinian politics, likely until a final status solution can eventually be found (Sharp, 2004). While causing substantive resentment in the affected population, the need to leave the homeland did not sever the connection to the territory but rather motivated a continued struggle for return. The valuation of the land therefore increases as a result of the forced resettlement.

I argue that symbolic, strategic, and material aspects constitute three substantially relevant dimensions defining territorial value. Conceptually, these are clearly distinguishable and mutually exclusive, but empirically more than one feature can be relevant to the area settled by a group. The three dimensions are not binary concepts but rather might be present without actually acquiring salience, or gain varying degrees of saliency. My expectations for each of the territorial features based on the causal argument are developed in detail below.

Symbolic value. Symbolic value involves the relational relevance of territory and refers to intangible features such as homeland attachments, the relevance of historical autonomy, or length of residence in conflicts (Gurr, 1993; Siroky $\&$ Cuffe, 2015). These characteristics can lead its inhabitants to explicitly relate to the territory, covering diverse features such as sacred rivers and mountains, the remains of the capital of a historical kingdom dominated by the ancestors of the group, the fundamental dependence on territory due to traditional, land-dependent lifestyles, as well as the loss of autonomy. Sacred places are found to be the only symbolically relevant areas qualifying as indivisible in conflicts (Hassner, 2003), but homeland territory shows similar 
tendencies toward indivisibility (Toft, 2006). Other scholars argue that there is no such thing as actual indivisibility. Rather, side payments, shared usage, and other comparable strategies are seen as feasible solutions to all conflicts (Fearon, 1995). Alternatively, the opponents might lock themselves in to certain policy positions, which makes it impossible at later stages to find facesaving ways to adjust these positions, and makes the conflict appear indivisible (Goddard, 2006). Actors might also purposively use this lockingin approach to narrow their bargaining range and, consequently, strengthen their bargaining power.

My theory of claim-making states that symbolic territory provides sources of individual and group identities, and imparts perceptions of belonging. By increasing the cohesion of the group, this helps overcoming collective action problems, making mobilization more feasible. Territorial belonging increases the legitimacy of demands, for instance, when the group can credibly claim the land to be the cradle of their civilization and the basis of their existence, as is often the case with indigenous groups. I expect territory that is symbolically valuable to have higher chances to be associated with demands for SD by a subnational group than land that is devoid of symbolic relevance. Groups are more likely to conceive of territory as substantially relevant when it has symbolic value because the attachment to the land is central for defining group identity and securing group cohesion. The Tibetans, for instance, inhabit their historical homeland. Being united by religious belonging and led by a spiritual leader, residence in the homeland is critical for group identity, as the Tibetans consider some of the territory's features as sacred. This includes Mount Kailash in Western Tibet, which is venerated in several great Asian religions (Snelling, 1997). In addition to increasing group cohesion, symbolic aspects provide the community with an identity-relevant issue to mobilize around and therefore increase the chances for successful mobilization. While increasing the mobilization capacity of a group, symbolically relevant territorially related events might however also create significant degrees of resentment. Forced resettlements or the loss of autonomy can lead to substantial grievances, but, as I argue, tend to increase the symbolic valuation of the territory. Indicative is the example of the Chechens who received no assistance and still invested the high costs of returning to their homeland in the late 1950s after being deported to Central Asia in 1944 (Toft, 2003). While being relevant to symbolic aspects of territory, grievances are therefore a secondary mechanism in the mobilization process.

Strategic value. Strategically relevant terrain is "of significant military value to the target and challenger. Territory can have strategic military value because of its geographic features (e.g., a mountain pass) or due to the presence of key 
military installations (e.g., major target base site)" (Carter, 2010, p. 974). Fearon and Laitin (2003) were the first to highlight the relevance of terrain ruggedness in civil wars. They argue that rebels overcome their relative military disadvantage by selecting the site of conflict strategically. Inaccessible terrain such as rugged mountain areas help rebels compensate for their relative weakness, avoid detection, and impede the eradication of their bases (Carter, Shaver, \& Wright, 2015). Beyond the protecting characteristics of rugged terrain, rebels fight where they enjoy the support of the local populace, in particular by coethnics (Kalyvas, 2006). By providing protection and support for weak rebels, terrain ruggedness therefore provides advantages for violent claimants.

Relevant to the strategic location of territory is its relative position within the state, which defines the opportunity costs associated with defending the land in case of violent conflict for both the group and the state (Buhaug, Gates, \& Lujala, 2009). The intrastate loss-of-strength gradient suggests that regions in the periphery of the state are harder to reach militarily by government forces (Boulding, 1962). Groups settling peripheral areas close to the borders and far away from the capital and major cities therefore benefit from the reduced enforcement capability of the state in conflicts. In line with this expectation, secessionist violent conflict is found to be more common in geographically peripheral areas (Buhaug, 2006). Given their relative remoteness from the political and economic center, territorially peripheral groups face a higher probability of suffering from the unequal distribution of public goods and services by the state. The reduced capability of the state to enforce law and social order in the periphery together with the increased cost of doing so makes the state less willing to engage in long-lasting disputes. Peripheral groups therefore have higher chances to suffer from grievances due to the reduced administrative penetration ability of the state, and enjoy strategic advantages in case of violent conflicts. The state, in contrast, is expected to be less willing to engage in violent conflicts over self-government. I therefore expect to find mixed associations.

Material value. The material value of territory is defined by the natural resources it contains and is equivalent to intrinsic characteristics of the land. "Territory is of economic value if it contains natural resources that can generate revenue from export. Potentially profitable resources include energy sources (e.g., oil) or mineral deposits (e.g., iron ore)" (Carter, 2010, p. 974). This includes all material benefits that can be extracted from territory based on its natural endowment, which, in addition to natural resources, covers agricultural production, tax collection, and market provision. Sovereignty over resource-rich areas makes their extraction and trading more feasible, 
which in turn provides incentives to achieve or secure territorial control. In fact, distant but geographically concentrated resource deposits are found to be associated with secession (Le Billon, 2001b). Furthermore, illegal extraction and shady resource sales are more feasible in the periphery where the state's capacity outreach is limited (Humphreys, 2005).

The focus of this article is on petroleum and diamonds, for which the most reliable global georeferenced data are available. Case study evidence suggests that the recovery of oil deposits inspires separatist movements through the government's preemptive repression, as in Southern Sudan, or by triggering the formation of separatist armies, as in the case of Aceh, Indonesia (Ross, 2012). Petroleum plays an important role in intrastate claim-making through two mechanisms. Through a direct mechanism, oil deposits are a source of revenues for regional governments of autonomous regions or, in case of violent claims, for rebel groups. Oil richness improves the state's economic situation - at least in the short term - and enables welfare-oriented redistribution policies. Through this second, indirect mechanism, petroleum can therefore have a conflict-reducing effect in the short term. Diamonds are easily lootable due to their favorable value-to-size ratio and the relatively straightforward method of extraction, which varies with the type of deposits. Kimberlite diamonds, located in underground rocks, are industrially mined, whereas alluvial diamonds are found in rivers or in marine deposits and spread across large areas, where they can be comparatively easily extracted by unskilled workers using simple tools (Lujala, Gleditsch, \& Gilmore, 2005, p. 543). Empirically, revenues, particularly those derived from alluvial diamond mining, are found to have directly contributed to financing several civil wars, including Angola (Le Billon, 2001a) and Sierra Leone (Smillie, Gberie, \& Hazleton, 2000).

Resource deposits are usually not beneficial to local residents but rather promote the reproduction of elite patronage networks in such a way that only a small section of society benefits from the revenue extracted from the deposits. The ownership structure, however, affects both the degree of patronage network reproduction and accountability, as well as the involvement of violence (Wegenast, 2013). Beyond generating grievances and reproducing unaccountable regimes, resource deposits therefore have little relevance in explaining the causes of SD demands. Territory is not the source of group cohesion but rather the container of grievances that might lead to conflict, such as for the Ogoni in Nigeria, who protest massive environmental degradation caused by oil extraction. Given this indirect link between material value and the onset of SD demands, I expect to uncover a weak association.

In the following sections, I present the approach to testing my theory of SD claim-making, based on the following main hypothesis: 
Hypothesis: Groups inhabiting symbolically valuable territory are more likely to advance SD demands than groups situated in strategically or materially valuable terrain.

\section{Measuring Self-Determination}

\section{Data Basis and Case Selection}

I base the coding and group definition on the group list provided by the AMAR project, including about 1,200 communities worldwide (Birnir et al., 2014; Birnir et al., 2012). The main definitional criterion states that groups are "socially relevant," which is assigned "when people notice and condition their actions on ethnic distinctions in everyday life," in contrast to politicized identities, which arise "when political coalitions are organized along ethnic lines, or when access to political or economic benefits depends on ethnicity" (Fearon, 2006, p. 852). The coding therefore assumes no prior political mobilization of the group members, in contrast to the comprehensive Ethnic Power Relations (EPR) and Minority at Risk (MAR) data sets, where political relevance and systematic discriminatory treatment, respectively, are the main inclusion criteria (Cederman, Wimmer, \& Min, 2010; Minorities at Risk Project, 2009). These approaches have limitations for my study, given the potential concern that groups are already mobilized for other reasons and that territorial value only provides the spark triggering conflict or violence in an already tense environment. Excluding the mobilization criterion in my analysis helps avoiding omitted variable bias.

Using the AMAR list, I code those groups that have at least one faction making claims for SD, demanding "greater autonomy, and at the extreme, independence" from the state (Cunningham, 2013b, p. 292). ${ }^{6}$ The coding relies on the Peace and Conflict 2005 report, which includes territorially concentrated groups demanding self-governance (Marshall \& Gurr, 2005). SD groups are defined as "a group of people that shares a collective identity and believes it has a legitimate right to self-rule" (Cunningham, 2014, p. 13).

I compare groups demanding self-rule to non-claimants using a case-control design (Goldstone et al., 2010; King \& Zeng, 2001). This approach allows for tracing systematic differences in the role of territory for claimants and non-contenders. Cases are chosen by selecting on the variable of interest $Y$, which is in this case a complete sample of SD groups according to both the AMAR and the Peace and Conflict report. Control cases for which $Y=0$ are identified through drawing a random sample (online appendix). Here, the number of observable $Y=1$ amounts to 128 , whereas the selection of observations for which $Y=0$ is based on a simple random sample ${ }^{7}$ of equal size 
from the remaining AMAR groups, where $n=1,031$. The resulting sample therefore consists of 256 observations (online appendix). The groups are assigned to (each of) the states where they are settled, resulting in group-state dyads as the units of observation.

\section{Data Description}

My theory of claim-making proposes that territorial value provides strong incentives for groups to make demands for SD toward the government. From existing approaches, it is not clear why territorially concentrated groups perceive of their land as valuable and identity-relevant as the nationalism literature has shown. Existing studies mostly focus on individual aspects of territorial value or use rough proxies to measure it. In the following section, I identify my empirical strategy to respond to these gaps.

Symbolic value. Several proxies have been developed to capture symbolic value, including the indirect measures of residence length and historical autonomy (Siroky \& Cuffe, 2015). However, relying solely on these indicators should be reconsidered for two reasons. First, residence in a certain area does not necessarily imply relevance of the land for group cohesion. A group might, for instance, inhabit a territory for a long time without the land gaining salience in everyday life. In contrast, territory matters substantially for indigenous groups, for whom it is both historically and in the present the primary basis of subsistence as well as the major political, cultural, and spiritual space. Second, historical autonomy might no longer be relevant for the group, as in some cases the loss thereof is lamented for decades, and in others the historical autonomy loses its meaning over time. Furthermore, recording whether the territory settled is the group's homeland is applied as a measure of symbolic relevance. This indicator is conceptually more closely related to SD than the two alternatives, and yields compelling predictions for the incidence of ethnic violence (Toft, 2002). Nevertheless, several limitations exist. First, the usually binary homeland measure makes no distinction as to what element of the territory accounts for its particular symbolic appeal. It therefore remains unclear which concrete element is relevant for homeland value assignment. Second, the measure fails to capture variation in symbolic attachment resulting from changes in the saliency of territory, which may for instance occur when groups are dispossessed from their land. Third, the mechanism seeks to explain ethnic violence, whereas this article is concerned with accounting for why groups demand SD and is not limited to violent events. In addition, the relevance of sacred space as a symbolic value indicator has so far not been studied in a comparative quantitative design. 
To attend to these gaps in measuring symbolic relevance, I propose and develop a new, more comprehensive, and direct measure. Building on suggestions from the nationalism literature, this new indicator links the religious, politico-historical, as well as culture- and lifestyle-related meaning of the territory specific to the inhabiting group to territorial characteristics such as sacred spaces or historical relevance of the land (Etherington, 2010; Smith, 1996, p. 454). In order to counter potential endogeneity concerns, at least two of four dimensions are present in each case for the symbolic value indicator to be coded 1. Information for the following four dimensions is collected:

1. Cultural value is coded when territorial characteristics are critical for the culture of the group. This includes nomadic or traditional lifestyles, or the presence of UNESCO World Heritage sites, such as the Kasubi Royal Tombs of the Baganda in Uganda, or the historical Nubian Meroe Pyramids in Sudan.

2. Religious value includes sacred sites that are of particular importance for the group inhabiting the area. In some cases, these are included in the UNESCO World Heritage list. This dimension comprises diverse sites, such as the Osun-Osogbo Sacred Grove of the Yoruba in Nigeria, or the sacred mountains and lakes of the Tibetans.

3. Political value captures the historical relevance of an area, such as a historical kingdom or historical territorial autonomy. This applies, for instance, to the Cabindans in Angola, whose historical territorial autonomy was established with the Treaty of Simulambuco of 1885 , or the historical kingdom of the Adja in Benin.

4. Land rights issues are captured in the final dimension, covering cases where groups are dispossessed from their land or forcefully displaced. This is often relevant for indigenous groups, whose demands in many cases involve protection against governments or international firms seeking to control indigenous territory for resource extraction. Examples include forced expulsions and land confiscations of Lhotshampas in Bhutan, or the forced resettlement of Crimean Tartars under Stalin.

Where applicable, the coding is geographically specific to the area settled by the group, for instance where sacred places or World Heritage sites are spatially assigned to the relevant group. The coding of the four dimensions is based on a wealth of sources, drawing from, where applicable, the MAR Risk Assessments (Minorities at Risk Project, 2009) and the World Directory of Minorities and Indigenous Peoples (Minority Rights Group International, 
2015). In addition, I relied on reports by human rights organizations and nongovernmental organizations (NGOs) such as Amnesty International, Human Rights Watch, or the International Crisis Group, and on various case study articles from academic journals, academic working papers, as well as news reports. Encyclopedias, particularly by Olson (1996) and Weekes (1978), but also by Minahan (1996) as well as the Britannica, and country studies by the Library of Congress provided helpful additional information. Information taken from group advocacy websites or blog posts is included after careful cross checking with additional reliable sources. Using multiple types of sources helps countering potential reporting bias stemming from the type of resource or agency providing the information.

Settlement patterns. To determine the spatial extent of the settlement patterns, to which both georeferenced and spatially non-explicit information are merged, I use the georeferenced version of the EPR, the GeoEPR 2.0 (Wucherpfennig, Weidmann, Girardin, Cederman, \& Wimmer, 2011). Of the 256 group-state dyads in my data set, 90 are not included in GeoEPR, for which I draw the settlement patterns myself using ArcGIS. For the necessary details, I rely on the maps and descriptions provided in the Ethnologue database (Lewis, Simons, \& Fennig, 2014) but also refer to various policy reports, maps from the Map Collection of the University of Texas (University of Texas, 2015), newspaper articles, as well as advocacy group websites. I cross-check all codings in GeoEPR and correct them where necessary. To identify the settlement pattern of the groups, I add a numerical indicator distinguishing different types following the GeoEPR coding (Bormann, 2011). Four of the original GeoEPR settlement patterns are present in the data set: regionally based, urban, regional and urban, as well as dispersed groups. Throughout the article, I make the pragmatic assumption that groups claim the territory they settle. Figure A1 in the online appendix illustrates how the settlement areas are combined with grid-based information in ArcGIS.

Material value. The coding of material territorial value relies on a combination of the geospatially localized positions of diamond and petroleum deposits. Georeferenced information for both types of resources is taken from the PRIO diamond dataset DIADATA (Gilmore, Gleditsch, Lujala, \& Rød, 2005) and the petroleum data collection PETRODATA (Lujala, Rød, \& Thieme, 2007). In the first step, I spatially associate information on deposit presence with the areas settled by the groups, which is later collapsed into a dummy variable indicating whether oil and diamonds, respectively, are found on the group territory. For the indicator measuring material value, I use the dichotomous resource deposit 
variables to create a dummy variable indicating diamond and oil occurrence. It is coded 1 if diamonds or oil, or both occur on the territory, and 0 otherwise.

Strategic value. The measure of territorial elevation constitutes a major innovation over existing data on mountainous terrain, which was first introduced into the study of civil war by Fearon and Laitin (2003). I use global data available from the National Aeronautics and Space Administration's (NASA) Oak Ridge National Laboratory Distributed Active Archive Center (DAAC, 2004). The data are transformed into a measure of ruggedness at the squared (30 arc seconds) grid level by Riley, DeGloria, and Elliot (1999), which is first applied to the field of conflict research by Shaver, Carter, and Shawa (2016). The "Terrain Ruggedness Indicator" is a relative measure that is calculated as a function of absolute elevation change between equally sized neighboring square units (Riley et al., 1999). The second indicator accounting for the strategic relevance of the territory is the distance from the capital, based on PRIO-Grid, where the absolute distance in kilometers of a given grid cell from the capital is measured (Tollefsen, Strand, \& Buhaug, 2012).$^{8}$ For measuring strategic terrain, I first calculate the mean values of both the logged elevation measure and the logged distance from the capital for the group territory, and collapse both into dichotomous variables. In a second step, I compute a combined indicator of the resulting logged average relative elevation and logged average distance from the capital. The indicator is coded 1 if at least one of the two variables is above their means, otherwise it is 0 .

Additional indicators. The geospatial data are complemented by disaggregated group-specific and aggregated national data. These include group characteristics, such as population size, existence of a demand for SD, and the involvement of violence. ${ }^{9}$ On an aggregated level, oil and diamond production figures, and population sizes are recorded. All variables are listed in the online appendix with a brief description and source information.

Data set. Given the data structure, the resulting data set is characterized by little variance in the indicators for material and strategic value. The creation of a time-series design for symbolic value is not feasible in the context of this study given the extensive qualitative information and the large number of observations. The data set therefore has cross-sectional structure and captures information for the year 2005, corresponding to the information available in the list of SD conflicts (Marshall \& Gurr, 2005). Following most large- $n$ studies of SD and subnational group conflict, I use group-state dyads as units of analysis, as groups are usually the subject and object of SD demands. 


\section{Analysis}

\section{Model Specification}

I use logistic regression estimations to explain the presence of demands for self-governance by the endowment of the territory settled by the respective group with symbolically, strategically, and materially valuable territory. Given the case-control design that guided the case selection process, I treat the data as survey data (cf. King \& Zeng, 2001; Lumley, 2010) and define the stratifying variable by the presence of SD demands in each case. Probability weights are specified as the inversed sampling probability of an observation (online appendix). The weighted observations are used to estimate the core model as

$$
\begin{aligned}
\operatorname{Pr}(\mathrm{SDG})_{j k}= & \beta_{0}+\beta_{1} \text { symbolic territory }_{j k}+\beta_{2} \text { strategic territory }_{j k} \\
& +\beta_{3} \text { material territory }_{j k}+\varepsilon_{j k} .
\end{aligned}
$$

where $j$ is the subscript for a group in country $k$. This core model is contrasted with additional estimations that compare the contributions of each of the territorial predictors. In addition, I include logged regional economic development per capita, regime type, and logged relative population size as control variables, and introduce alternative model specifications (online appendix).

Frequencies and relative shares of each of the dichotomous territorial value indicators, distinguishing between claimants and non-contender, are presented in Figure 1. A clear majority of almost two thirds of the SD groups inhabit symbolic territory, whereas only $18 \%$ of the non-disputant communities have symbolic bonds to the land. Strategic terrain overall is a more common characteristic. A large share of the groups inhabits strategic terrain, with a higher number of claimants settling this type of territory. Only one third of the SD groups have no resource deposits on their land, but diamonds and oil are found on the territory of more than half of the communities not demanding self-rule.

Figure 2 illustrates differences between groups demanding SD and communities not disputing their status, highlighting the potential for variance underestimation when comparing SD cases to a heterogeneous baseline category. The histograms show the distribution of observations with different combinations of the three territorial value dimensions, conditional on the SD characteristic. More than twice as many non-disputant groups in comparison to claimants inhabit territory that is valuable on only one dimension, symbolic, strategic, or material. Very few claimants settle territory that is not valuable at all, whereas about $40 \%$ inhabit land that is valuable on all three dimensions, which applies to less than $10 \%$ of the communities not making any demands. For the cases where territory is valuable on two of the maximum three dimensions, the picture is equally varied. Only a handful of 


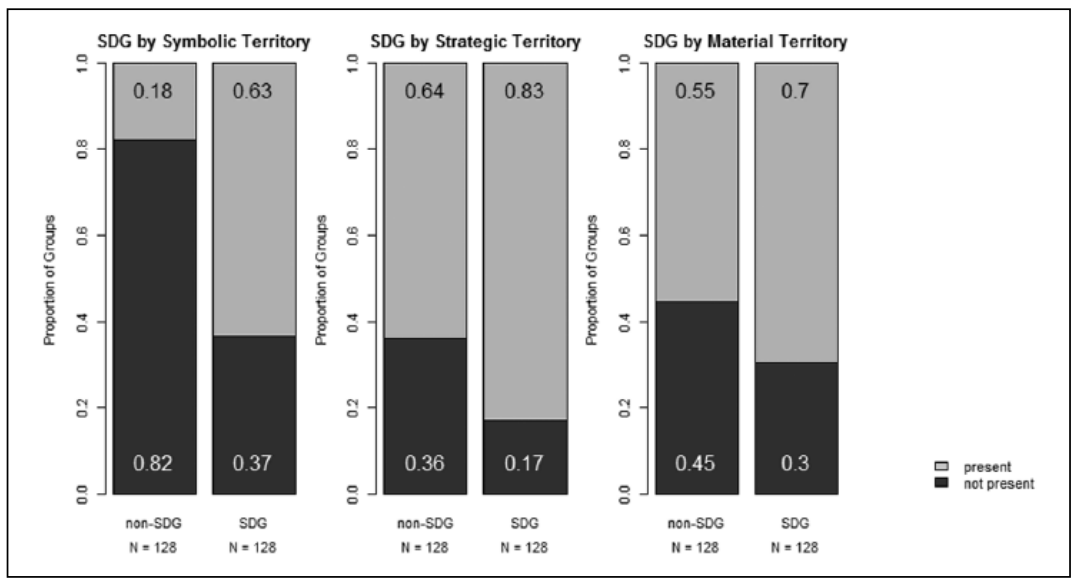

Figure I. Distribution of self-determination groups (SDG) by type of territorial value.

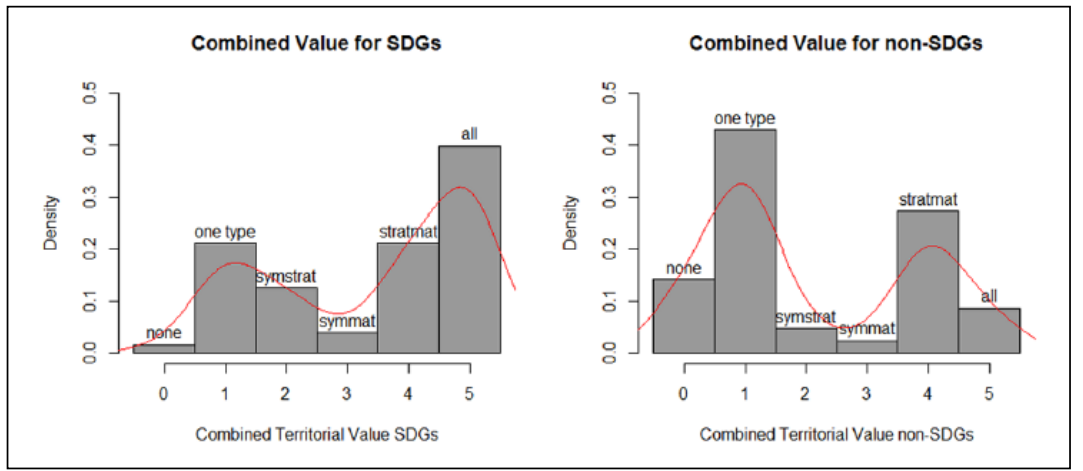

Figure 2. Histograms of the distribution of territorial value dimensions by selfdetermination characteristic with density line.

non-disputants settle territory with symbolic and strategic, and symbolic and material value, respectively. Strategically and materially valuable land is characteristic of about a third of the groups not demanding greater rights. For claiming groups the distribution of the share of groups settling territory valued on two different dimensions varies significantly between less than $5 \%$ and about $20 \%$ of the communities.

Based on the comparison of territorial value across different values for $\mathrm{SD}$, pronounced differences between the groups are apparent. Ignoring this 
Table I. Logistic Regression Estimates, Reporting Odds Ratios of the Presence of Demands for Self-Determination.

\begin{tabular}{|c|c|c|c|c|c|}
\hline & Model I & Model 2 & Model 3 & Model 4 & Model 5 \\
\hline Symbolic value & $7.87^{* * * *}(2.32)$ & & & $7.13^{* * * *}(2.17)$ & $7.54^{* * * *}(2.35)$ \\
\hline Strategic value & & $2.70 * * *(0.8 \mathrm{I})$ & & $2.11 * *(0.74)$ & $2.10 *(0.82)$ \\
\hline Material value & & & $1.83 * *(0.48)$ & I.57 (0.50) & I.54 (0.62) \\
\hline Regime type & & & & & $\mathrm{I} .04(0.03)$ \\
\hline $\begin{array}{l}\text { Log group } \\
\text { population }\end{array}$ & & & & & $1.02(0.09)$ \\
\hline $\begin{array}{l}\text { Log local } \\
\text { economic } \\
\text { activity }\end{array}$ & & & & & $0.92(0.14)$ \\
\hline Constant & $0.06 * * *(0.01)$ & $0.06 * * *(0.01)$ & $0.08 * * *(0.01)$ & $0.03 * * *(0.01)$ & $0.04 * * *(0.04)$ \\
\hline Model fit & 1.00 & 1.00 & 1.00 & 1.00 & 0.00 \\
\hline$N$ & 256 & 256 & 256 & 256 & 242 \\
\hline
\end{tabular}

Linearized standard errors are in parentheses. Data are treated as survey data to account for probability weighting and stratification in the case-control design.

$* p<.1 . * *_{p}<.05$. ***p $<.01$.

variance across the values of the dependent variable implies overestimating the simultaneous presence of strategic, material, and symbolic territorial value, while at the same time underestimating the number of cases where no territorial value is present. This provides initial evidence for the relevance of my argument to not only disaggregate territorial value into its multiple dimensions and comparatively assess their respective relevance but to also investigate systematic differences of SD groups and communities not claiming greater rights as a necessary prerequisite for a better understanding of violence in conflicts over self-rule.

\section{Findings}

The main results of the logistic regression model estimations are shown in Table 1. Groups that value their land for symbolic reasons have higher chances of making demands for self-rule across all five models, which supports the core hypothesized relationship. The odds of claiming SD for a group settling symbolic territory are significantly higher than for any of the other territorial characteristics. The association between the incidence of SD demands and strategic terrain is in the expected direction, reaching conventional levels of statistical significance. The positive association of resource presence and claims for self-governance is not robust to the inclusion of additional value measures or control variables. Both models estimating the individual effects 
of each of the territorial predictors as well as Model 5, which includes the control variables, provide evidence for these findings. Symbolic territory is clearly the most important predictor associated with demands for SD, while none of the control variables reaches statistical significance. With the survey data design, the assumption made in maximum likelihood estimation regarding the independent and identical distribution of observations is not met. Instead of the pseudo- $R^{2}$, I therefore report results of Hosmer-Lemeshow goodness-of-fit tests. Applying the goodness-of-fit tests to the models in Table 1 suggests no evidence of lack of fit, apart for Model 5 after including the control variables.

The main intuition is supported by the predicted probabilities, based on the main estimates in Model 4 (online appendix). The probability that a community demands greater self-rule increases by about $23 \%$ when groups value their land for symbolic reasons in comparison to land that is not symbolically valuable. The differences are much smaller for strategically and materially relevant territory, suggesting that symbolic value is a key characteristic distinguishing between non-claiming groups and communities struggling for SD. For territory that is not valued on any of the three dimensions, the expected probability for SD demands is below 3\%.

The results hold independent of the coding rule applied to measure the key explanatory variable symbolic territorial value. The original coding used in Model 4 assigns symbolic value to a piece of land if at least two of the four subtypes of symbolic value - cultural, religious, and political value and land rights issues - apply to the territory. To account for potential endogeneity concerns, I specify two new binary variables measuring symbolic value. For the liberal coding, the variable assumes the value 1 if at least one dimension of symbolic value characterizes the territory. For the conservative specification, I assign the value 1 if three or more of the four elements are present. I include and compare each of the variables in estimations of the core model including material and strategic territorial value. The coefficient plot in Figure 3 supports the earlier findings indicating that symbolic territory is consistently more strongly associated with the incidence of SD demands than material or strategic value (for results see online appendix). In contrast to the presence of resource deposits, the measure of strategic value is positive and significant across all there specifications. The probability that groups struggle for SD when they value symbolic aspects increases sharply with stricter specifications of the symbolic value indicator, supporting the general intuition. While in the liberal estimation the chances for SD demands increase by about $16 \%$ in comparison to groups without symbolic attachments, it rises to $25 \%$ when the strict specification is applied (online appendix). 


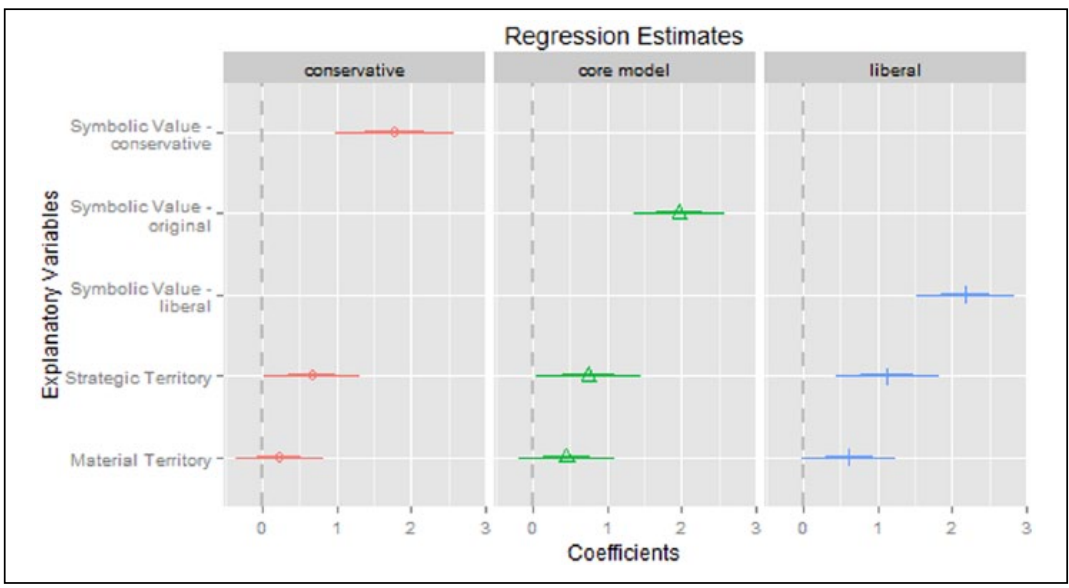

Figure 3. Coefficient plot comparing specifications of symbolic territory.

In territorial demands, actors might relate to one or more dimensions based either on the factual presence of value-relevant characteristics, or in order to add leverage to a claim for SD. The strong findings for the relevance of symbolic territory in accounting for the incidence of SD demands might be a remnant of this strategy. Group grievances induced by resource extraction are an example. As the associated future revenues would benefit group elites and not the average group member, referring to the symbolic value of the land can increase the salience of the issue to the group audience, thereby disguising the less compelling source of the demand. To account for this empirical possibility, I estimate interaction models including all three value dimensions as well as interaction effects for symbolic territory with material and strategic value, respectively. Strong findings for material and strategic terrain would imply that symbolic value succeeds the two alternative value dimensions and contradict my theoretical argument.

The findings plotted in Figure 4 suggest that this is not the case (for results, see online appendix). While statistically significant associations between the three value dimensions and the demands for self-government are established in almost all models, no statistically significant relation of the interactions of material and strategic territory with symbolic value is uncovered. The probabilities for the incidence of SD demands conditional on the value endowment of the land including interaction effects suggest similar results (online appendix). This finding is plausible, because although the "invention of tradition" is common in nation building attempts (cf. 


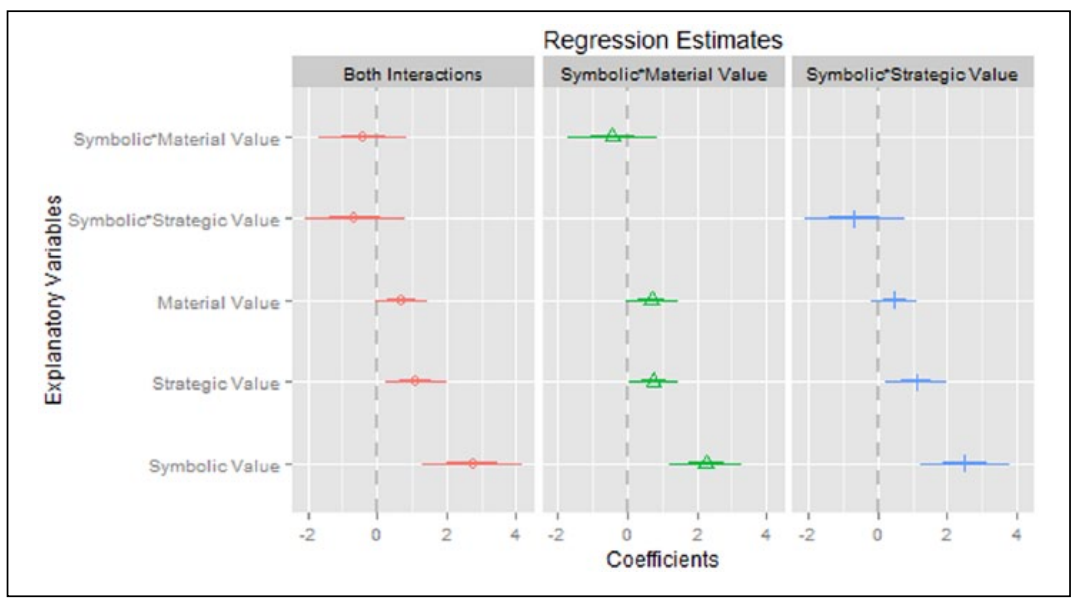

Figure 4. Coefficient plot comparing interactions of territorial value.

Hobsbawm \& Ranger, 2012), the creation of factually completely unfounded territorial attachments is implausible. In fact, "nationalists cannot, and do not, create nations ex nihilo. There must be, at least, some elements in the chosen population and its social environment who favor the aspirations and activities of the nationalist visionaries" (Smith, 1989, 343). The until today rather unsuccessful attempts to create coherent nations out of very heterogeneous populations in post-colonial states in Sub-Saharan Africa or Asia provide ample evidence against the arbitrariness of nationalist identity creation (cf. Smith, 1996, p. 448). Furthermore, in his case study of the Golan heights, Hassner (2006/2007) describes how Jewish Israeli settlers excavated remains of historical synagogues in order to substantiate their demand to the land. If there are, for instance, no historical remnants to unearth in order to provide evidence in favor of the own claim, the demand cannot be credibly supported. While it is critical for any group to secure access to basic resources, if possible by territorial control, the need for resource control can empirically be overridden by symbolic attachments to the territory, as demonstrated by the intentional Zionist choice of the resource-poor region at the Eastern shore of the Mediterranean to build a modern Jewish state (cf. White, 2000, p. 23). Additional disaggregated research is required to allow for reliable causal statements. However, the assumption that symbolic value is not an independent source for demands for SD, but that territory valued for material and strategic reasons is consequentially also embraced on a symbolic dimension by its inhabitants, can be rejected. 
I estimate multiple additional model specifications to ensure model robustness, which are discussed in the online appendix. The results support the earlier findings.

\section{Conclusions}

In this article, I present a new comprehensive theory of subnational claimmaking seeking to understand the characteristics of territory in conflicts over SD, and investigating which features of the land affect a group's propensity to demand self-rule. While the nationalism literature establishes the relevance of territorial characteristics for nationalist identities, no conceptual and empirical basis is provided to account for the question how and why nationalists relate to territory. I argue that symbolic territory shows greater saliency in SD struggles than strategic or material value, due to its relevance for group cohesion. While all three territorial features can affect grievances, which might in turn lead to mobilization for self-rule, the relation between symbolic value and SD demands has a more direct quality. I argue that symbolic features of the land provide groups with identity-relevant issues to mobilize around, increasing the capacity to overcome collective action problems through strengthening the group identity. Introducing new data, I forward an empirical design contrasting claimants to non-disputant groups and compare symbolically, strategically, and materially valuable terrain in order to assess their relevance for explaining which groups demand self-governance.

In sum, I identify the following patterns in the data. First, the odds for SD demands are consistently higher for groups inhabiting symbolically valuable territory compared with the two alternative dimensions. Materially valuable land offers a statistically significant but non-robust contribution to the estimations. Strategic territory is consistently positively associated with demands for self-rule but not as strong as symbolic territorial attachments. Second, a similar pattern is apparent when considering the predicted probabilities for SD incidence conditional on average values on each of the value dimensions. Again, the presence of symbolic value shows the strongest association. Depending on the model specification, groups are up to about 10 times more likely to make a demand for SD when they value their territory for symbolic reasons in comparison to non-valuable land. In sum, the findings for all three value dimensions are in line with my theoretical expectations.

Future work will assess the role of the three value dimensions conditional on the degree of violence involved in more detail. The extension of the territorial value measures over time will help to understand its association with 
the incidence of SD demands better. Furthermore, the unitary actor assumption, which for the purposes of this article is reasonable in order to ensure model parsimony, will be revisited.

The theoretical approach and the data presented in this article respond to the theoretical and empirical gaps identified. Assessing three different elements that define territorial value using comprehensive measures serves to establish a holistic conceptualization of territory as an intrinsically relevant asset in demands for $\mathrm{SD}$. The data set provides a representative selection of control cases for comparison with groups demanding self-rule, which makes it possible to identify the systematic differences in terms of the association between territorial value and struggles for self-government between claimants and non-disputant groups.

\section{Author's Note}

Earlier version of this article have been presented at the 73rd Annual Conference of the Midwest Political Science Association in Chicago, the 5th Annual General Conference of the European Political Science Association in Vienna, the workshop "The Political Economy of Inequality and Conflict" at the University of Konstanz, as well as the 111th Annual Meeting of the American Political Science Association, all in 2015. I thank the participants for their helpful feedback. All mistakes of course remain my own responsibility.

\section{Acknowledgments}

I thank Nils-Christian Bormann, David Carter, Kathleen Gallagher Cunningham, Hein Goemans, Paul Huth, Gerald Schneider, Christina Zuber, and three anonymous reviewers for excellent comments and suggestions.

\section{Declaration of Conflicting Interests}

The author(s) declared no potential conflicts of interest with respect to the research, authorship, and/or publication of this article.

\section{Funding}

The author(s) disclosed receipt of the following financial support for the research, authorship and/or publication of this article: The article is based on research funded by a doctoral fellowship of the German National Academic Foundation ("Studienstiftung des deutschen Volkes").

\section{Notes}

1. For all self-determination (SD) groups, I recorded the start date of the demand and temporal origin of sources of symbolic value. For instance, based on the Marshall and Gurr (2005) list, I assigned 1988 as the start date of the Tuareg claim in Niger. This is a nomadic group with traditional lifestyle. The Tuareg 
were dispossessed from their lands in 1917 and lost their autonomy in 1922. The demand for self-rule clearly appeared significantly later than the events connected to the relevant sources of symbolic value. A detailed list for all SD cases can be found in the online appendix.

2. While groups are not nations per se, their pursuit of political self-governance characterizes them as such (White, 2000, p. 17).

3. In fact, a significant share of the literature considered in this article is concerned with violent conflict or not specific to SD demands. I argue that the mechanisms nonetheless apply across conflict strategies and conflict issue, as mobilization is critical for all types of collective action. An analysis of the relevance of violence suggests that my assessment of the literature does not miss a significant amount of variation in the data (online appendix).

4. To my best knowledge, Walter (2003), who investigates the sources of territorial conflict, constitutes the only exception.

5. I thank two anonymous reviewers for pointing this out.

6. "Demands for autonomy include scope-related demands, such as increased control in substantive areas (for example education, cultural affairs, taxing and spending powers) and for changes in the organization of the state to devolve decision making (such as the creation of a regional government). General democratization demands are not coded as self-determination demands unless there was specific mention of a change in the level or scope of the population's governance (such as federalism)." The terms "autonomy, self-determination, self-governance, self-rule, federalism, and independence" are considered as synonymous (Cunningham, 2013a, p. 1).

7. A stratified sample of the control group might have led to more efficient estimators. I thank an anonymous reviewer for pointing this out.

8. The relevance of the distance to the capital in conflict processes varies depending on the size of the country and the accessibility of the area. In a small state with well-developed infrastructure, a large distance has a smaller impact on the lossof-strength-gradient or the development of grievances than the same distance in a large country with a less developed road network. I therefore divide the absolute distance measure provided in PRIO-Grid by the national average values, which I use to generate dichotomous variables in a second step. The same approach is taken for the elevation measure and the binary relative strategic value measure created. The results, reported in the online appendix, show that the relative strategic terrain measure does not reach conventional levels of statistical significance.

9. For details on the coding and the association of violence and territorial value, see the online appendix.

\section{References}

Birnir, J. K., Wilkenfeld, J., Fearon, J. D., Laitin, D. D., Gurr, T. R., Brancati, D., . . . Hultquist, A. S. (2014). Socially relevant ethnic groups, ethnic structure, and AMAR. Journal of Peace Research, 52, 110-115. doi:10.1177/0022343314536915

Birnir, J. K., Wilkenfeld, J., Fearon, J. D., Laitin, D. D., Gurr, T. R., Brancati, D., . . Pate, A. (2012). The reason we don't yet know "why groups rebel": Introducing 
AMAR (All-Minorities at Risk). Unpublished manuscript, University of Maryland, College Park.

Bormann, N.-C. (2011). Geo-referencing Ethnic Power Relations (GeoEPR-ETH) Version 2.0. Zurich, Switzerland. Retrieved from http://www.icr.ethz.ch/data/ other/geoepr-2.0/geoepr-eth_v.2.0_codebook.pdf

Boulding, K. E. (1962). Conflict and defense: A general theory. New York, NY: Harper \& Row.

Buhaug, H. (2006). Relative capability and rebel objective in civil war. Journal of Peace Research, 43, 691-708. doi:10.1177/0022343306069255

Buhaug, H., Gates, S., \& Lujala, P. (2009). Geography, rebel capability, and the duration of civil conflict. Journal of Conflict Resolution, 53, 544-569. doi:10.1177/0022002709336457

Carter, D. B. (2010). The strategy of territorial conflict. American Journal of Political Science, 54, 969-987.

Carter, D. B., Shaver, A. C., \& Wright, A. L. (2015). Places to hide: Terrain, ethnicity, and political violence. Unpublished manuscript, Princeton University, NJ.

Cederman, L.-E., Wimmer, A., \& Min, B. (2010). Why do ethnic groups rebel? New data and analysis. World Politics, 62, 87-119.

Chenoweth, E., \& Lewis, O. A. (2013). Unpacking nonviolent campaigns: Introducing the NAVCO 2.0 dataset. Journal of Peace Research, 50, 415-423. doi: $10.1177 / 0022343312471551$

Cunningham, K. G. (2013a). Supplementary information for: Actor fragmentation and civil war bargaining: How internal divisions generate civil conflict. American Journal of Political Science (AJPS), 57, 659-672. Retrieved from http://onlinelibrary.wiley.com/doi/10.1111/ajps.12003/suppinfo

Cunningham, K. G. (2013b). Understanding strategic choice: The determinants of civil war and nonviolent campaign in self-determination disputes. Journal of Peace Research, 50, 291-304. doi:10.1177/0022343313475467

Cunningham, K. G. (2014). Inside the politics of self-determination. Oxford, UK: Oxford University Press.

DAAC, L.P. (2004). Global 30 Arc-Second Elevation Data Set GTOPO30. Land Process Distributed Active Archive Center. Retrieved from http://webmap.ornl. gov/wcsdown/wcsdown.jsp?dg_id=10003_1

Etherington, J. (2010). Nationalism, territoriality and national territorial belonging. Papers: Revista de sociologia, 95, 321-339.

Fearon, J. D. (1995). Rationalist explanations for war. International Organization, $49,379-414$.

Fearon, J. D. (2006). Ethnic mobilization and ethnic violence. In B. R. Weingast \& D. Wittman (Eds.), Oxford handbook of political economy (pp. 852-868). Oxford, UK: Oxford University Press.

Fearon, J. D., \& Laitin, D. (2003). Ethnicity, insurgency, and civil war. American Political Science Review, 97, 75-90.

Gilmore, E., Gleditsch, N. P., Lujala, P., \& Rød, J. K. (2005). Conflict diamonds: A new dataset. Conflict Management and Peace Science, 22, 257-292. 
Gleditsch, K. S., \& Rivera, M. (2015). The diffusion of nonviolent campaigns. Journal of Conflict Resolution. doi:10.1177/0022002715603101

Goddard, S. E. (2006). Uncommon ground: Indivisible territory and the politics of legitimacy. International Organization, 60, 35-68.

Goemans, H. E. (2006). Bounded communities: Territoriality, territorial attachment, and conflict. In M. Kahler \& B. F. Walter (Eds.), Territoriality and conflict in an era of globalization (pp. 25-61). Cambridge, UK: Cambridge University Press.

Goldstone, J. A., Bates, R. H., Epstein, D. L., Gurr, T. R., Lustik, M. B., Marshall, M. G., ... Woodward, M. (2010). A global model for forecasting political instability. American Journal of Political Science, 54, 190-208.

Gurr, T. R. (1993). Minorities at risk: A global view of ethnopolitical conflict. Washington, DC: United States Institute of Peace Press.

Hassner, R. E. (2003). To halve and to hold: Conflicts over sacred space and the problem of indivisibility. Security Studies, 12(4), 1-33.

Hassner, R. E. (2006/2007). The path to intractability: Time and entrenchment of territorial disputes. International Security, 31, 107-138.

Hechter, M., \& Okamoto, D. (2001). Political consequences of minority group formation. Annual Review of Political Science, 4, 189-215. doi:10.1146/annurev.polisci.4.1.189

Herb, G. H. (1999). National identity and territory. In G. H. Herb \& D. H. Kaplan (Eds.), Nested identities: Nationalism, territory, and scale (pp. 9-30). Lanham, MD: Rowman \& Littlefield.

Hobsbawm, E., \& Ranger, T. (2012). The invention of tradition. Cambridge, UK: Cambridge University Press.

Humphreys, M. (2005). Natural resources, conflict, and conflict resolution: Uncovering the mechanisms. Journal of Conflict Resolution, 49, 508-537. doi: $10.1177 / 0022002705277545$

Jenne, E. K., Saideman, S. M., \& Lowe, W. (2007). Separatism as a bargaining posture: The role of leverage in minority radicalization. Journal of Peace Research, 44, 539-558.

Kalyvas, S. N. (2006). The logic of violence in civil war. Cambridge, UK: Cambridge University Press.

King, G., \& Zeng, L. (2001). Logistic regression in rare events data. Political Analysis, 9, 137-163.

Le Billon, P. (2001a). Angola's political economy of war: The role of oil and diamonds, 1975-2000. African Affairs, 100, 55-80. doi:10.1093/afraf/100.398.55

Le Billon, P. (2001b). The political ecology of war: Natural resources and armed conflicts. Political Geography, 20, 561-584. doi:10.1016/s0962-6298(01)00015-4

Lewis, M. P., Simons, G. F., \& Fennig, C. D. (2014). Ethnologue: Languages of the world. Dallas, TX: SIL International.

Lujala, P., Gleditsch, N. P., \& Gilmore, E. (2005). A diamond curse? Civil war and a lootable resource. Journal of Conflict Resolution, 49, 538-562.

Lujala, P., Rød, J. K., \& Thieme, N. (2007). Fighting over oil: Introducing a new dataset. Conflict Management and Peace Science, 24, 239-256.

Lumley, T. (2010). Complex surveys: A guide to analysis using R. Hoboken, NJ: Wiley. 
Marshall, M. G., \& Gurr, T. R. (2005). Peace and conflict 2005: A global survey of armed conflicts, self-determination movements, and democracy. College Park: Center for International Development and Conflict Management, University of Maryland.

Minahan, J. (1996). Nations without states: A historical dictionary of contemporary national movements. Westport, CT: Greenwood Press.

Minorities at Risk Project. (2009). Minorities at risk dataset. Retrieved from http:// www.cidcm.umd.edu/mar/

Minority Rights Group International. (2015). World directory of minorities and indigenous peoples. Retrieved from http://minorityrights.org/directory/

Olson, J. S. (1996). The peoples of Africa: An ethnohistorical dictionary. Westport, CT: Greenwood Press.

Penrose, J. (2002). Nations, states and homelands: Territory and territoriality in nationalist thought. Nations and Nationalism, 8, 277-297.

Purser, J. (1992). Scotland's music. A history of the traditional and classical music of Scotland from earliest times to present day. Edinburgh: Mainstream Publishing Company.

Riley, S. J., DeGloria, S. D., \& Elliot, R. (1999). A terrain ruggedness index that quantifies topographic heterogeneity. Intermountain Journal of Sciences, 5, 23-27.

Ross, M. L. (2012). The oil curse: How petroleum wealth shapes the development of nations. Princeton, NJ: Princeton University Press.

Sharp, H. (2004, April 15). Right of return: Palestinian dream. BBC News. Retrieved from http://news.bbc.co.uk/2/hi/middle_east/3629923.stm

Shaver, A. C., Carter, D. B., \& Shawa, T. W. (2016). Terrain ruggedness and land cover: Improved data for all research designs. Conflict Management and Peace Science.

Siroky, D. S., \& Cuffe, J. (2015). Lost autonomy, nationalism and separatism. Comparative Political Studies, 48, 3-34. doi:10.1177/0010414013516927

Smillie, I., Gberie, L., \& Hazleton, R. (2000). The heart of the matter: Sierra Leone, diamonds and human security. Ottawa: Partnership Africa Canada.

Smith, A. D. (1989). The origins of nations. Ethnic and Racial Studies, 12, 340-367. doi:10.1080/01419870.1989.9993639

Smith, A. D. (1996). Culture, community and territory: The politics of ethnicity and nationalism. International Affairs, 72, 445-458. doi:10.2307/2625550

Snelling, J. (1997). The sacred mountain: Travellers and pilgrims at Mount Kailas in Western Tibet, and the great universal symbol of the sacred mountain. London, England: East West Publications.

Toft, M. D. (2002). Indivisible territory, geographic concentration, and ethnic war. Security Studies, 12, 82-119.

Toft, M. D. (2003). The geography of ethnic violence: Identity, interests, and the indivisibility of territory. Princeton, NJ: Princeton University Press.

Toft, M. D. (2006). Issue indivisibility and time horizons as rationalist explanations for war. Security Studies, 15, 34-69. doi:10.1080/09636410600666246 
Toft, M. D. (2012). Self-determination, secession, and civil war. Terrorism and Political Violence, 24, 581-600.

Tollefsen, A. F., Strand, H., \& Buhaug, H. (2012). PRIO-GRID: A unified spatial data structure. Journal of Peace Research, 49, 363-374. doi:10.1177/ 0022343311431287

University of Texas. (2015). Perry-Castañeda library map collection. Retrieved from http://www.lib.utexas.edu/maps/

Walter, B. F. (2003). Explaining the intractability of territorial conflict. International Studies Review, 5, 137-153.

Weekes, R. V. (1978). Muslim peoples: A world ethnographic survey. Westport, CT: Greenwood Press.

Wegenast, T. (2013). The Impact of fuel ownership on intrastate violence (GIGA Working Paper No. 225). Hamburg.

Weidmann, N. B. (2009). Geography as motivation and opportunity: Group concentration and ethnic conflict. Journal of Conflict Resolution, 53, 526-543.

White, G. W. (2000). Nationalism and territory: Constructing group identity in Southeastern Europe. Lanham, MD: Rowman \& Littlefield.

Wucherpfennig, J., Weidmann, N. B., Girardin, L., Cederman, L.-E., \& Wimmer, A. (2011). Politically relevant ethnic groups across space and time: Introducing the GeoEPR dataset. Conflict Management and Peace Science, 28, 423-437.

\section{Author Biography}

Friederike Luise Kelle is a doctoral candidate at the Graduate School of Decision Sciences at University of Konstanz, Germany. 